DOI: $10.22363 / 2313-2337-2021-25-2-582-600$

\author{
Research Article
}

\title{
Critical evaluation of English and Saudi insurance law: A case for reform
}

\author{
Khalaf M. Albalawi \\ Tabuk University, \\ Tabuk, Saudi Arabia, \\ km.albalawi@ut.edu.sa
}

\begin{abstract}
The global significance of English law continues, particularly in Saudi as it is the most frequently chosen insurance policy law. Both jurisdictions provide consumer protections in insurance markets including the Consumer Insurance (Disclosure and...) Act and the 2015 Insurance Act and the Insurance Consumer Protection Principles 2014 in Saudi Arabia. This study aims to analyse the current reform impact on the interpretation of these doctrines between the UK and Saudi jurisdictions. In the last few years British insurance law has been significantly reviewed and modified and the most recent amendments, as per the Insurance Act 2015, are of the greatest significance and will be given due consideration within this paper. However, both the rationale for the reforms and the reform process will be reviewed as well as the UK perspective of the increasing rivalries between countries on account of legal business.
\end{abstract}

Key words: English, Saudi, insurance, law reform, non-disclosure, misrepresentation, warranty

Conflicts of interest. The author declared no conflicts of interest.

Article received 6th September 2020

Article accepted 15th April 2021

\section{For citation:}

Albalawi, K.M. (2021) Critical evaluation of English and Saudi insurance law: A case for reform. RUDN Journal of Law. 25 (2), 582-600. DOI: 10.22363/2313-2337-2021-25-2-582-600 


\title{
Критическая оценка английского и саудовского законодательства о страховании: аргументы в пользу реформы
}

\author{
Х.М. Альбалави \\ Университет Табука, \\ 2. Табук, Саудовская Аравия, \\ km.albalawi@ut.edu.sa
}

\begin{abstract}
Аннотация. Мировое значение термина «English Law» cохраняется, особенно в Саудовской Аравии, поскольку это наиболее часто выбираемый закон о страховых полисах, обе юрисдикции обеспечивают защиту потребителей на страховых рынках, включая Закон о страховании потребителей (раскрытие информации и заверения) и Закон о страховании 2015 г. в Великобритании от 2012 г., а также страхование. Принципы защиты прав потребителей 2014 г. В Саудовской Аравии. Это исследование направлено на анализ влияния нынешней реформы на интерпретацию этих доктрин между юрисдикциями Великобритании и Саудовской Аравии.

Ключевые слова: английский, саудовский, страхование, законодательная реформа, неразглашение, введение в заблуждение, гарантия
\end{abstract}

Конфликт интересов. Автор заявляет об отсутствии конфликта интересов.

Дата поступления в редакиию: 6 сентября 2020 г.

Дата принятия к печати: 15 января 2021 г.

\section{Для цитирования:}

Albalawi K.M. Critical evaluation of English and Saudi insurance law: A case for reform // RUDN Journal of Law. 2021. T. 25. № 2. C. 582-600. DOI: 10.22363/2313-2337-2021-25$2-582-600$

\section{Introduction}

There is no doubt that insurance law is vital and as Benjamin Franklin once opined, "nothing is certain in life except for death and taxes". In the modern context, insurance could be added to what Franklin said as all modern projects, plans, initiatives, and businesses often require a range of insurance policies to be in place. Yet with that, English insurance law, which for years held a preeminent position in the world, is far from perfect although it is the choice of many international insurance contracts. Both practitioners and academics are required to possess a thorough understanding of English insurance law and where Lloyd's contracts are subject to English law. Therefore, its imperfections are evident in certain aspects and this article intends to outline the most significant and relevant reforms which have recently occurred. These reforms will revolve largely around the principles of pre-contractual utmost good faith and the regulations related to warranties. 


\section{The Process of Insurance Reform in the United Kingdom}

A wide-ranging review of English insurance law has been under way for several years and according to the Law Commission there was room for reform. English insurance law is world renowned and has been the benchmark for insurance across the globe with international contracts opting for English law as the choice of law. However, up until very recently, English insurance law was based on principles developed in the $18^{\text {th }}$ and $19^{\text {th }}$ centuries and codified in the Marine Insurance Act of 1906, which applied to both marine and non-marine insurance. However, the Marine Insurance Act was insurer-focused and was designed to protect the insurer against exploitation. This law a hundred years later was not deemed as reflecting modern business transactions and the ways in which people communicate, store, or assess information. Due to this, and since the 1980s when its first report was issued, the Law Commission decided that the outdated principles, precepts, and rules embodied in the Marine Insurance Act 1906 required updating, modernising, and reviewing for the contemporary insurance landscape. There was no immediate legislative change in insurance after the Law Commissions report in the 1980 s although it reported breaches of warranty, nondisclosure, and misrepresentation (Merkin \& Lowry, 2008; Lowry, 2009). In the year after the publication of the report both the Ombudsman Scheme for Financial Services and the Insurance Ombudsman Bureau was established (McGee, 2015:76). The Law Commission's work also involved equalising between both insurer and the insured from a neutral perspective. This was to redress a relationship that was regarded by many commentators, legal experts and consumer insurance experts as being unfair.

\section{Consumer and non-consumer transactions}

A further point worthy of consideration is the emergence of a separation of rules governing commercial transactions and those governing consumer transactions (which can also be referred to as 'non-commercial transactions'); this article will use both terms.

In general terms, commercial transactions are where both parties come to an agreement to exchange items of value and such transactions cover business, whereas in consumer transactions this is true only for one party. The Unfair Contract Terms Act 1977 and the Unfair Terms in Consumer Contracts Regulations 1999 are two examples of rules which differentiate between the two. Furthermore, recent reviews and reforms to the Law of Sale of Goods, as seen with the addition of a passage from the Consumer Rights Act 2015, which states that it is only applicable to contracts of a consumer nature and permits the right to reject goods in forms which do not apply to the Commercial Goods Act 1979.

As will be further investigated below, this differentiation is considered valid as consumers are collectively seen as being in weak bargaining positions when juxtaposed to businesses. Consumers are also viewed as having a weaker grasp of the governing rules. Thirdly, consumers require greater assistance when agreeing contractual terms. The emergence of this differentiation in rules demonstrates a clear departure from 
Victorian notions of 'freedom of contract' which cases such as L'estrange v Graucob could be said to represent ${ }^{1}$.

\section{Utmost Good Faith}

The doctrine of 'utmost good faith' is clearly defined in Section 17 of the Marine Insurance Act 1906 (the MIA), wherein it is relayed as follows:

A contract of maritime insurance is a contract based on the utmost good faith, and, if the utmost good faith be not observed by either party, the contract may be avoided by the other party.

The same rule is known to be in place for non-marine insurance. The strictures of the Act, and in particular Section 18, which comprehensively outlines the duty of pre-contractual disclosure, place the burden on the proposer ${ }^{2}$.

According to s33(3) the above definition of a warranty provides a condition to be adhered to regardless of its degree of relevance to the risk. Were the condition to be broken, then following the provisions granted by the policy, the insurer's liability is removed from the date of the violation of the warranty, but without prejudice to any legal obligation from him incurred before that date.

It is evident that the test is unquestionable, a warranty breach immediately removes the insurer's liability regardless of intention, recklessness, or negligence. As stated below, the second sentence has been revoked. Once more, the same rules hold for non-marine insurance. The rule's impact can be very severe. Any accidental violation, even if the insured is oblivious to it, can result in the insured being left essentially without cover, even without an obvious causal link between the breach and $\operatorname{loss}^{3}$.

The Consumer Insurance (Disclosure and Representations) Act 2012 demonstrates how insurance law has followed the trend towards differentiating commercial and consumer transactions. The Consumer Insurance (Disclosure and Representations) Act $2012^{4}$ applies, as may be expected, solely to consumer insurance.

The provisions of section 2, regarding duty of disclosure, are vital. This section states that the consumer's disclosure stipulations and representations to an insurer in the period prior to a consumer insurance contract being made. The consumer is required to be reasonably careful to avoid a false statement to the insurer. Should the consumer fail to comply with the insurer's requirement for confirmation or amendment of any previously given particulars, at this point this may constitute a misrepresentation as per the Act. The responsibilities outlined in Section 2(2) supersede any responsibilities concerning consumer disclosure or representations to an insurer, which occurred prior

\footnotetext{
${ }^{1}$ L'estrange v Graucob (1934) 2K.B. 394.

${ }^{2}$ See: Monde Petroleum SA v Western Zagros Ltd (2016) EWHC 1472 (Comm). No implied duty of good faith in termination clause. 16 September 2016.

${ }^{3}$ See Yam Seng Pre Ltd v International Trade Corp Ltd (2013) EWHC 111 (QB); Monde Petroleum SA v Western Zagros Ltd (2016) EWHC 1472 (Comm); and National Private Air Transport Services Co (National Air Services) v Creditrade LLP (2016) EWHC 2144 (Comm).

${ }^{4}$ Insurance Act 2012, Schedule 2, Paragraph 1.
} 
to the application of the Act. This may be seen as the key element of Section 2. The previous wide-ranging MIA duty of disclosure is invalidated in consumer insurance, being supplanted by this new, more streamlined duty.

Any rule of law stating that a consumer insurance contract is one of utmost good faith is modified to the degree mandated by the requirements of this Act. Additionally, the administration of Section 17 of the Marine Insurance Act 1906 (that marine insurance contracts are of utmost good faith) in relation to a marine insurance contract that it is consumer insurance and must comply with the provisions of this $\mathrm{Act}^{5}$. The phrasing of this section implies that Section 17 has merely undergone modification alone. While it is true that Section 17 has not been repealed, the impact of section 2 of the 2012 Act is dramatic. The preceding stringent disclosure rules have been minimised to a far less burdensome duty, to take reasonable care to avoid a misrepresentation. Thus, there is no longer a pro-active duty of disclosure. Providing no deliberate misrepresentation takes place, the consumer is seen to have met the requirements of the duty, even if material omissions are present (Merkin \& Gürses, 2015; Birds, 2016:20-21).

As a result, most key cases on non-disclosure or misrepresentation in consumer insurance become invalid, both policyholders and insurers move into uncharted waters. These impacts are considered next.

Section 6 of the 2012 Act is of critical importance for warranties as this section deals with consumer representations in relation to a planned consumer insurance contract, or planned adaptation to a consumer insurance contract (Lowry \& Rowling, 2012; Merkin, 2016). Such representations cannot be transformed into a warranty by a provision of the consumer insurance contract or any other contract or by announcing the representation to be the contract basis. Thus, no consumer insurance warranty may stem from the proposal form, yet this does not mean that no warranties may exist in the policy. Any misrepresentations arising, including any occurring on the proposal form, may cause the remedies in Schedule 1, Part 1 to the 2012 Act, which are fundamentally comparable to those in the 2015 Act, to be put into practice (Tyldesley, 2013:51).

\section{The Insurance Act 2015}

The Insurance Act 2015 came into force on the 12h August 2016 and was based on a draft bill produced by the Law Commission. It introduced significant changes to the MIA 1906.

Section 2 of the Act, Duty of Fair Presentation, applies to non-consumer contracts; it provides that the insured must make a fair presentation of the risk. This term is familiar to English insurance litigators and was invented in the early 1980s by Lord Justice Carr. The Insurance Act 2015 notes that the fair presentation of risk makes the required disclosure, in a manner which is reasonably clear and accessible to a prudent insurer in which every material presentation to a matter of fact is substantially correct and every material representation to a matter of expectational belief is made in good faith.

\footnotetext{
${ }^{5}$ Insurance Act 2012, Schedule 2, Paragraph 5.
} 
This is very close to what was enshrined in the 1906 Marine Insurance Act; however, a new stipulation is that the disclosure has to be made in a manner which is "reasonably clear and accessible". This wording, however, did not feature "fair presentation' in the law up until this point. It was formulated to reflect the principle, which has been developed in UK law recently; it means that the crucial details and information of material fact are hidden in documentation, which an insurer will not read. In this way, the Insurance Act 2015 21(2) repeals Sections 18-20 of the MIA 1906 by dispensing with utmost good faith in the context of the assured's precontractual duties and replaces it with the notion of fair presentation, mentioned in English legal cases before 1906, e.g., Bates v Hewitt (1866-1867) and Morrison v The Universal Marine Insurance Company (1872-1873). This was regarded by the Law Commission as a better formula of the proviso (Noussia, 2019:583-584).

Our focus in this article applies to non-consumer insurance contracts alone, that is, contracts where the insured acts in the interests of his/her own business. Therefore, the 2015 Act can be viewed as the complement to the 2012 Act. Similarly, it deals with non-disclosure, warranties, and misrepresentation provisions, however, these are less beneficial than the 2012 Act.

\section{Disclosure}

The IA 2015 includes new provisions regarding the duty of disclosure and like the MIA includes waiver provisions. It also explains how information must be disclosed and by whom, and the new duty reflects the dissemination of IT in gathering information in large companies and organisations (Noussia, 2019:586).

Regarding disclosure, Section 3 outlines the terms of duty of fair presentation. This requires every material circumstance known to the insured, or those which the insured might be expected to know, to be revealed. Should this not occur, disclosure providing the insured with adequate information to warn an insurer that further investigations into those material circumstances is needed (Merkin, 2016). Should no enquiry take place, there is no obligation to reveal a circumstance if it lessens the risk; the insurer is, ought to be or is assumed, to be aware of it.

It is evident that this interpretation is an alteration of the disclosure rules of Section 18 of the MIA, yet it also plainly centered on that interpretation and does not seek to be or deemed to be known to the insured. In other words, it ceases to be a stringent prerequisite as under S18. The new requirement of warning the insurer of the need to make further enquiries is likely to provide the insured with some ability to avoid the penalties of non-disclosure. ${ }^{6}$ Therefore, previous disclosure cases under S18 may retain some relevance under the new law, while cases related to what the insurer is assumed to know, should still be deemed important. Noussia (Noussia, 2019:585) discusses the matter of knowledge and that it is a marked departure from the MIA, although the later Act is consistent with the earlier in that S3(4) highlights that the assured has to disclose only what is known or ought to be known in usual business dealings.

\footnotetext{
${ }^{6}$ Insurance Act 2015, Schedule 3, paragraph 4.
} 
Regarding the penalties of non-disclosure, S17's outwardly comprehensible phrasing was diluted by the 1995 verdict of the House of Lords (Lords Templeman, Goff, Mustill, Slynn and Lloyd) in Pine Top v Pan Atlantic ${ }^{7}$. That case demonstrated that a theoretical rational of insurer would be affected by the undisclosed issue, i.e., if the issue had been disclosed the insurer would have come to a different conclusion. This obligation is now an explicit part of the new law, which exceeds the Pine Top ruling, by providing a variety of potential remedies in cases where lower cover or more expensive premiums might have been offered. With this in mind, the closing words of the MIA S17 are also altered by S8 of the 2015 Act by providing the insurer with a remedy against the insured for violations of the duty of fair presentation. Should the insurer demonstrate that, were it not for the violation, the insurer would not have been party to the insurance contract in any way, or had they done so would have demanded different terms ${ }^{8}$.

In the case of a deliberate or reckless qualifying violation, it is possible for the insurer to escape the contract, reject all claims, and withhold from any premiums paid. In the absence of a qualifying violation, the insurer would not be party to a contract on any terms, and thus may escape the contract and reject all claims. However, in this situation, they must return the premiums paid. Were the insurer to have become party to the contract, but on other terms (other than premium related terms) the contract should be treated as though it had been contracted on other terms if required by the insurer. Moreover, had the insurer become party to the contact (regardless of whether the terms relating to issues apart from the premium differed or not), and charged a higher premium, the insurer may decide to make proportionate reductions to the amount to be compensated on a claim ${ }^{9}$.

\section{Warranties}

In insurance law contracts a warranty is a fundamental term in contract to general law wherein it carries a lesser significance and wherein a breach of warranty gives rise to damages but not to a right of discharge, and breach of a condition gives rise to both damages and a right of discharge. In insurance law it is largely reversed as an insurance warranty is a pre-contractual promise by the insured that a given fact is true, will remain true or that $\mathrm{s} /$ he will do, or not do, certain actions. A warranty must be complied with regardless of whether it is material to the risk or not. A warranty was defined by the MIA S33(1) as a promissory warranty, that is to say, a warranty by which the assured undertakes that some particular thing shall or shall not be done or that some condition shall be fulfilled, or whereby he affirms or negates the existence of a particular state of facts.

Based on this, a warranty enshrines a promise by the insured to do or not do certain actions and/or promise that a certain situation is true. If a warranty is broken it can result in harsh consequences for the insured such as avoidance of the policy by the

\footnotetext{
${ }^{7}$ Pan Atlantic Insurance Co. Ltd v Pine Top Insurance Co. (1995) 1 AC 501 (dealing with the statutory test of materiality in respect of non-disclosures and misrepresentations inducing insurance contracts).

${ }^{8}$ Insurance Act 2015, Schedule 6, paragraph 2.

${ }^{9}$ Insurance Act 2015, Schedule 8, paragraph 2.
} 
insurer. In order to identify a warranty no particular formula of words is required; it can be created by a clear statement or implied expression of terms (i.e., in a motor insurance policy that the car is roadworthy at all times) and is the basis of contract clauses which convert pre-contact representations into warranties.

Promissory warranties in marine insurance law are of more importance than in contract law wherein warranty can be regarded as just a term in a contract, which if breached is remedied in damages (Hodges, 1999:269). Section 35(1) notes that an express warranty may be in any form of words. What can be inferred from this is that as long as intention to warrant is present, a promissory warranty may be in a standard form in whichever manner the contracting parties wish to frame it so long as both parties agree.

According to the MIA a warranty has the following characteristics: it must be exactly complied with; it does not have to be material to the risk; there is no remedy to the breach; there is no defence of the breach and it is a promissory condition precedent. Firstly, the warranty being exactly complied with as per S33(3) of the MIA was evident as early court cases noted that there was a requirement to differentiate between what is amounted to compliance with a warranty and compliance with a representation. This came to light in Pawson $v$ Watson (1778) where the court summed up that a warranty inserted in a policy of insurance must be literally and strictly complied with. A representation to the underwriter needs only be substantially performed.

Herein, during the American War of Independence, the British vessel Julius Caesar was insured with the defendants for a voyage from England to Halifax, Nova Scotia. Under the insurance policy (the case has been discussed at length by Hodges, 1999:270), the ship had 12 guns and 20 men. Yet, the ship was captured by American privateers who had on board around 19 guns, 16 men and 9 boys. The insurers refused to indemnify the assured. The court ruled that the condition only amounted to a representation and not a warranty, because the condition was not a written part of the policy. While in De Hahn v Hartley (1786) a policy was underwritten on the basis of the crew of a vessel, the Juno, being 50 men strong or more when in reality it was 46 men. When the ship Juno was captured the insurers were held not liable for the loss because there had been a breach of the warranty to supply a sufficient crew. While in the case of Overseas Commodities Ltd $v$ Style (1958) the plaintiffs shipped two consignments of tinned pork from France to London under an all-risks policy of insurance underwritten by the defendants. The policy contained a clause that all the tins should be marked with the date of manufacture for verification. However, most of the tins, upon arrival, were damaged, rusty, and not sellable. The plaintiffs claimed on their policy of insurance; however, the insurers did not accept the claim as most tins did not have the date of manufacture on them. So, the plaintiffs were deemed as having been in breach of the warranty. The words for verification in the clause were held by the court to mean that the tins must have the date clearly written on them. As most tins did not have dates clearly demarcated this was taken as a breach of warranty. The defendants therefore were not liable.

Warranties have a variety of meanings and can be divided into present warranties and continual warranties. This has been outlined by Colinvaux (2010) in his Law of Insurance. He asserted that an insurance condition is "either an obligation on the 
assured to act in a particular way, or a contingency — which may be outside the control of the assured - upon which the validity of the policy or of any claim may depend".

One of the outcomes of the Law Commission's reforms was to do away with the basis of contract clauses for consumer insurance contracts with the Consumer Insurance (Disclosure and Representation) Act 2012 and for non-consumer contracts as per the Insurance Act 2015. Within both, a representation cannot be converted into a warranty by means of any provision of the insurance contract or any other contract.

Section 10 of the Insurance Act 2015 discusses warranties in non-consumer contracts and that breach of a warranty will not discharge the insurer's liability if the breach of warranty has been remedied before the loss. The remedy of a breach of promissory warranty is to regard warranties as suspensive conditions where cover is restored if the breach of the warranty has been duly remedied. Nevertheless, although this change deals with the matter of how to remedy a breach of the warranty it still falls short in a number of issues such as no causal link between breach and loss, instant suspension of the cover and strict compliance. Wang notes (Wang, 2017:170) that there are two distinct weaknesses with the 2015 Act when it comes to warranties. Firstly, that it requires strict compliance with the warranty and secondly that regardless of how trivial any illegal breaches of the warranty are, the losses are rendered unrecoverable.

A similar sense to that of S6 of the 2012 Act can be seen in the Warranties S9 of the 2015 Act. It is not possible to transform a proposed non-consumer insurance contract, nor a proposed alteration to a non-consumer insurance contract, to a warranty by using any form of non-consumer insurance contract provision, or of any other type of contract (regardless of whether the representation is seen to be the foundation of the contract or not). This sense is maintained in S10 of the 2015 Act by stating that if an insurance contract warranty (be it implied or express) is violated by a rule of law, then the insurer's liability under the contract is ended ${ }^{10}$.

The new rule states than an insurer is not liable under an insurance contract regarding losses that may occur, or be attributed to an event taking place, after a contract warranty (implied or express) has been violated but prior to the violation being resolved. However, should there be a change in the conditions the warranty becomes invalid as regards the conditions of the contract, or compliance with the warranty; it becomes unlawful due to the imposition of any subsequent law or violation of the warranty is waived by the insurer ${ }^{11}$.

Additionally, under sub-section (2) the liability of the insurer in respect of losses taking place or being attributable to something taking place prior to the warranty violation, or if violation can be resolved, following the resolution remaining unaffected. The insured is awarded additional safety regarding the policy terms (as opposed to terms, which specify the risk as a whole) where compliance may be likely to lessen the risk of a number of different kinds of loss, such as specific location, or specific time. In the event of a loss, where the terms have not been met, the insurer may not depend on this non-compliance to dismiss, restrict, or discharge their contract obligations for the loss. This is also the case when the insured demonstrates that the non-compliance

\footnotetext{
${ }^{10}$ Insurance Act 2015, Schedule 8, paragraph 2.
}

${ }^{11}$ Insurance Act 2015, Schedule 10, paragraph 4. 
term does not amplify the risk of loss. As a result, violations, which may be demonstrated (and the burden to demonstrate it lies with the insured), do not add to the risk occurred, so cannot burden the insurer ${ }^{12}$.

\section{General Comments}

There is no doubt that English insurance law needed reform and hence since 2006 the Law Commission invested enormous resources into the project, including the two statutes discussed in the article, which are unquestionably significant. However, more time and experience are needed to assess the impact of these reforms and for this a substantial body of case law is necessary. As the acid test of effectiveness of commercial law is its practical effect, its evaluation may be problematic. The aim of this legislation is to differentiate between consumer and non-consumer insurance and to balance more fairly the concerns of insurer and insured. This task is certainly very challenging.

Certainly, the balance to some degree now favours the insured, especially in consumer over non-consumer insurance, as would be expected with the thinking given above. Consideration of the degree of disclosure necessary involves the question of what information insurers need. Insurers believe that it is necessary to have every possible detail about a risk. While this is understandable it is neither necessarily correct nor practical. In insurance some uncertainty is inevitable. Loss rate data, which can be analysed in various ways, is always to hand. A practicable rating schedule is viable without having to hand the large amount of information, which insurers claim to need, meaning that deciding a commercially workable premium, while achieving a profit, or at worst a small loss, can be achieved.

The result of this may, however, be that a larger number of poor risks are taken. Consequently, premiums may rise although this proposition has yet to be proven. Insurance economies are different areas in relation to insurance law and is neglected in academic study in England. As for the matter of warranties, then all kinds of different arguments prevail and are given. It is clear that warranties can cover issues, which are pertinent to the risk, and that compliance with such warranties is something insurers are entitled to insist on, yet, the history of insurance law is awash with instances where S33 of the MIA has deprived the insured of cover, as a consequence of seemingly trivial or irrelevant violations. Warranties remain permissible in policies, but statements on the proposal may not be transformed into warranties (Merkin \& Gürses, 2016:8-9). Section 11 of the 2015 Act offers added protection for the non-consumer insured, and the rules on remedies for misrepresentations offer some small limitations on the freedom of insurers to sidestep.

It is possible to suggest that certain issues remain with this area of reform. One may hope that reliance on such warranties will diminish, but opportunity remains for insurers to sidestep the Act's intention by merely broadening the variety of warranties in a policy, without considering them in the proposal form. However, greater issues are still to be solved in insurance law, and the Law Commission continues its diligent work

\footnotetext{
12 Insurance Act 2015, Schedule 10, paragraph 4.
} 
in this area. For instance, insurable interest requires an amount of re-consideration. It is fair to say that progress has been made to fit the insurance law into the purposes relevant in the $21^{\text {st }}$ century. The hope is that, as a result, England will be able to maintain its place as a world leader in insurance services, in addition to managing the careful balance of interests between insurers and particularly the consumer insured.

\section{Insurance Reform in the Kingdom of Saudi Arabia}

According to Saudi Basic Law of Governance, the highest law in Saudi Arabia and the bedrock of its constitution is the Shariah (Divine Islamic Legislation) under which all other regulations and laws must fall and if there is any contradiction the said new legislation must be abolished. Until 2003, the Kingdom of Saudi Arabia did not have its own applicable insurance law and it was in that year that the first Law on Supervision of Cooperative Insurance Companies (2003) was passed. It stipulated that all insurance companies operating within the KSA must do so in a cooperative manner or in tandem with the Shariah (Divine Islamic Legislation).

Nevertheless, this law does not meet some fundamental facets of insurance contracts, including insurance principles and party obligations as it focuses on overseeing the market itself. As a result, several statutory disparities remain, not to mention the fact that the Islamic jurists within the KSA are still particularly averse to its institution. Indeed, in other research I have noted that Islamic jurists regard an insurance contract as falling within the remit of Bay' ul-Gharar (the uncertain transaction). The Gharar (uncertain risk) within insurance is not slight whatsoever, it is either major or median and the most accurate view is that it is major Gharar. This is because an insurance contract has to involve 'khatar' (risk or danger) and this refers to a probable accident that occurs despite the wishes of either party. Insurance cannot be paid unless there is a future accident which is unanticipated, so Gharar is a binding factor for insurance contracts and is one of the distinguishing features of insurance contracts. This therefore renders it a type of Gharar which is forbidden in Shariah.

Despite the Commercial Court Law 1931113 (CCL) being identified as the oldest example of national commercial law, covering terms for marine insurance in articles 324-289, the CCL is ineligible in practice since the Commercial Court was not established until 2017 and its terms are deemed too unclear. Furthermore, the CCL may be used only as a guidance in cases for arbitration. It was the Ministry of Finance that issues the first declaration in this area (No. 1/596 dated 21/04/2004) namely the Implementing Regulation of the Law on Supervision of Cooperative Insurance Companies 2004 (IRLSCIC). It covers several fundamental principles of insurance and in art meets a number of needs, formerly revealed by the LSCIC. Saudi Arabian Monetary Authority's regulations (SAMA) is answerable for issues arising in the insurance sector. Appropriately, as part of its remit, SAMA has created several regulations related to key insurance procedures.

The key regulations cover the Insurance Market Code of Conduct Regulation 2008 (IMCCR), the Anti-Fraud Regulation 2008 (AFR) and Online Insurance Activities Regulations 2011 (OIAR). Of key importance is the fact that SAMA has now put the Insurance Consumer Protection Principles 2014 (ICPP) into practice. Further 
regulations covering particular insurance types, including the Unified Compulsory Motor Insurance Policy 2011 (UCMIP), Cooperative Health Insurance Law 1999 (CHIL) and Implementing Regulation of Cooperative Health Insurance Law 2014 (IRCHIL). While Saudi Arabia has processes and laws to administer insurance in KSA, a number of important omissions remain, including comprehensive guidelines and limits on legal principles, obligations, legal remedies and, most importantly, the principle of good faith.

\section{Utmost Good Faith}

While the principle of utmost good faith is not applied in Saudi law and regulation in theory, it is, in practice, recognised and therefore given credence as a general principle in Islamic contract provisions.

Oddly, neither of the Saudi insurance laws and regulations (whether the LSCIC 2003 or the IMCCR 2008) have not provided any details at all on the effect of breaching the duty of good faith on the insurance contract. The LSCIC 2003 provides that a person will face a penalty of no more than one million Saudi Riyals and/or a prison term no longer than four years for violation of the law or enforcement regulations ${ }^{13}$. It also provides disciplinary measures to be applied by SAMA, and SAMA can also request termination if a company continues to violate the law despite such measures ${ }^{14}$.

The IMCCR 2008 stipulates that any violation of the regulation will be deemed a breach to the licensing conditions and may subject the insurance company to an enforcement action. ${ }^{15}$ The LSCIC 2003 and the IMCCR 2008 therefore can both consider the breach of good faith a breach of a statutory duty, however this will only result in actions against the insurer, or any relevant intermediaries, and no benefits are derived for the assured. ${ }^{16}$

Key Islamic legal sources accept a high level of good faith without limitations. Yet the Islamic jurisprudential tradition and most of its corpus does not accept utmost good faith and provide any requirements to differentiate between the two principles. This is in direct opposition to the views and practice of UK jurisdiction (Aldiyabi, 2014:15, 32).

In the narrow sense of insurance contacts, the principle of utmost good faith is to reveal and offer pertinent material facts. This encourages the insurer to partake in the contract on particular terms and premiums, before and during the contract's duration. In the wider sense, it necessitates honest fair dealing in addition to the requirement to reveal and be clear and succinct in all contracts, including insurance contracts. A few Islamic scholars of law have given attention to the principle of utmost good faith and clarified it to be similar to the principle of good faith, i.e., to offer the necessary facts accurately and truthfully, to their contracted party (Abu Orabi, 2011:254).

Abu Orabi states that the key importance of the principle of utmost good faith within insurance contracts is due to the variation in the severity of remedies in

\footnotetext{
13 Art.21 LSCIC2003.

${ }^{14}$ Art.19 LSCIC2003.

15 Art.9 IMCOCR2008.

${ }^{16}$ Art.9 IMCOCR2008.
} 
comparison to other types of contracts, such as contracts of insurance termination, termination of insurance contract, the loss of the right to insurance over claims, and insurance contract avoidance. Abu Orabi differentiates between legal remedies associated with insurance contracts and other types of contract necessitating recognition of the difference between the principle of good faith and the principle of utmost good faith (Abu Orabi, 2011:183).

This type of legal remedy is already available and applicable in Islamic contracts for violation of the principle of good faith. However, it is worth noting that the principle of utmost good faith, the difference between the principle of good faith and utmost good faith are not recognised in the Saudi Arabian Monetary Authority's regulations (SAMA). Insurance principles, utmost good faith, and its consumer information function among them, can be found outlined on SAMA's website. However, SAMA states no difference between the principles of utmost good faith and good faith, nor does it use any insurance regulations to identify and explain these principles.

Consequently, SAMA seems to be adopting other jurisdictions' interpretation. However, the Islamic perspective on the principle of good faith is more fitting as it does not acknowledge any distinctions between utmost good faith and good faith. Most Islamic legal scholars do not state the principle of utmost good to be distinct from good faith, and therefore they are likely to adopt only the principle of good faith, since they do not see a specific need to implement such a distinction. Sharia law does not recognise the principle of utmost good faith, but, importantly, the principle of good faith encompasses utmost good faith. The Islamic Research Journal states that insurance contracts are based on the principle of good faith, seeing it as an essential element with faith, and reliability in this type of contact and consensual contracts (Thanasegaran, 2016:28).

Ordinarily, bad faith is considered a violation of the principle of good faith in Islamic contract law. Situations of bad faith, which arise when a violation of the duty of good faith occurs, are well-provided for under Sharia. Were the bad faith to have taken place before the contract's end and the claimant had proven this, as is their responsibility, it is possible for the contract to be declared void. If, however, the bad faith had taken place at a point during the contract, and was this proven, it would be possible to end the contract. As Saudi laws and regulations make no mention of legal remedy details, especially in cases of bad faith, universal Islamic contract requirements and principles will resolve this issue (Hasson, 1969).

In contrast, the approach of the General Secretariat of the Committees for Resolution of Insurance Disputes and Violations (CRIDV) to the issue in Saudi Arabia is to administer the principle of utmost good faith, but with further responsibilities ${ }^{17}$. This is applicable since the principle of utmost good faith may be administered in other ways, for instance, to enact the duty to notify in addition to the duty of the insured to clarify the policy exceptions. Additionally, the Law Commissions observed the judicial flexibility of good faith to resolve unusual and challenging difficulties. This perceived

\footnotetext{
${ }^{17}$ An official insurance dispute resolution and violation body is established in the Kingdom of Saudi Arabia; its website, which details reports and analyses. Available at: https://www.idc.gov.sa/en-us/Pages/default.aspx [Accessed 03 ${ }^{\text {th }}$ September 2020].
} 
flexibility may be a factor in the expansion of this principle. For instance, it has been deemed unreliable in balancing party relationships where the insurer may depend on their right to avoid paying a claim, when exercising of this right is unreasonable. Likewise, a CRIDV decision aimed to rebalance the contracting parties' situations based on utmost good faith. The Committee concluded that a strict reliance on the terms of the policy would injure the insured unjustly. Consequently, the Committee concluded the term to be arbitrary, and as a result, annulled it (Hasson, 1969).

Additionally, as the exchange of information should occur in good faith, the understanding of duty of fair presentation should be viewed with consideration of the principle of utmost good faith. A relevant example of this was offered by the Law Commissions. They note that if a court were to find that some material facts had been deliberately concealed by the insured, and there were not expected to be any additional queries about these facts and details, this would be seen as violation of the duty of fair presentation since the reading of this duty covers the need to act in good faith when offering information.

A resemblance can clearly be seen between the UK jurisdiction's duty of fair presentation and Saudi Arabia's duty of disclosure since both contain components of disclosure and the requirement to avoid misrepresentation. Considering this, many decisions have been viewed as violations of the duty of disclosure by CRIDV, constructed on this reading of the principle of utmost good faith. Examples of this will be given shortly. It is also important to note that if violation was not detrimental, or did not escalate the loss, it is not considered a violation.

By considering these three potential uses of the 'interpretative principle' of good faith, evidence suggests that good faith is viewed positively by Saudi and the UK jurisdictions. Additionally, the reading of these three potential uses seems not to applicable beyond those situations. Importantly, good faith is at the core of the duty of fair presentation may also be used to regulate dishonest claims. It is a feature of the regulation of a violation.

Consequently, the differences between the principles of utmost good faith, good faith, dishonest claims, and the duty of fair presentation of risks are evaluated largely through investigation of the remedies existing should a violation occur, rather than considering them as the course of the duty of fair presentation of risk or responsibility to make honest claims. Furthermore, although the principle of utmost good faith creates terms implicit in an insurance contract, the principle itself cannot be viewed as an implicit term ('Uthaymeen, 2002:65-67).

On the other hand, unlike what is seen in Saudi jurisdiction, the principle of utmost good faith influences other responsibilities concerning the use of good faith, as demonstrated previously, and not only in unusual or difficult cases. In all cases the principle of utmost good faith is requisite for insurance contracts to allow the collection of damages, if violation takes place, which is comparable to the model used in Australia. It was the opinion of other legal scholars that the interpretation of the wording of insurance contracts should include use of the principle of utmost good faith. This point of view received support in the form of the Law Commissions' example whereby the principle of utmost good faith is seen as a method of interpretation of the duty of fair presentation. 
The consequence of this is due to expanding the range of the principle of utmost good faith. Consequently, the principle of utmost good faith is more supple and useful than with the previous English approach, particularly after ending evasion as a remedy by S14 of IA. Thus, the reading of the duty of fair presentation of risks in business insurance or the duty of reasonable care to avoid misrepresentation in consumer insurance should be undertaken with due consideration of the principle of utmost good faith (Shukrī, 2011:721).

Furthermore, using the Law Commissions report as a basis, the first application of the principle of utmost good faith to understand the duty of fair presentation of risks, involved good faith in the information exchange, as codified in S3(3) of IA 2015. It is for the courts to consider future applications. However, while using the principle of utmost good faith as an explanatory principle, it is important to acknowledge two disadvantages. Firstly, both the Saudi and UK jurisdictions should consider the principle with a wider scope. The consequence of this may be a broader application than the current English common law position. Secondly, because of this, contracting parties, and particularly the insured, maybe unclear in their reading of the principle of utmost good faith. This is of key importance in consumer insurance and the lack of distinction between good faith and utmost good faith is being queried by customers and insurance employees. A possibility exists, therefore, for further confusion particularly among those insured parties without a professional knowledge of the topic and only a limited or a total lack of experience in consumer insurance in either jurisdiction (Hasson, 1969). This demonstrates the importance of the recent UK reform. Yet, it remains incomplete due to its focus on the insured alone, instead of offering a balanced view of responsibilities on both insuring and the insured parties (Lowry et al., 2011:128).

\section{Saudi Disclosure}

The KSA legal jurisdiction deems the entire market to be consumers and no distinction is made between businesses and consumers. In both cases the precontractual duty of the insured is wholly based on the principle of utmost good faith ${ }^{18}$. Similarities therefore exist between Saudi Arabia's approach and the UK's previous law, which was founded on the now abolished S18-20 of the MIA, covering not only the duty of disclosure and misrepresentation but also the duty of fair presentation of risks. Yet, Saudi jurisdiction upholds the duty of disclosure and misrepresentations; Article 5(1) of ICPP obliges consumers to offer truthful, complete, and exact answers about material facts during the form-filling and proposal process, which can be seen to be comparable to CIDRA but also including the requirement to disclose.

Article 2 of Insurance Consumer Protection Principles (ICPP) obliges consumers to avoid concealment from, and deception of, the insurer. Due to the numerous

\footnotetext{
${ }^{18}$ Decision No.70/R/1433H, which was upheld by appeal decision No.269/a/1436H (2015) of the Committees for Resolution of Insurance Disputes and Violations in Riyadh; decision No.128/R/1435H (2014), which was upheld by appeal decision No.704/a/1436H (2015) of the Committees for Resolution of Insurance Disputes and Violations in Riyadh; and decision No.38/J/1429 H (2008) of the Committees for Resolution of Insurance Disputes and Violations in Jeddah.
} 
differences between individual, corporate, and professional insurance, there is a clear need for acknowledgement of the market as the term consumers include both business and the individual insured in a similar manner in the UK context. It is vital that the Saudi jurisdiction adopts the duty of reasonable care not to make misrepresentation since individual consumers and businesses may have different degrees of understanding, experience, and knowledge (Shukrī, 2011:721).

The Saudi jurisdiction offers further consumer protection in the process of applying for insurance policies online. Articles 36 and 37 of OIAR oblige insurers to offer the insured their proposals, cover limits, terms and conditions and endorsements when online insurance policies are issued in Saudi Arabia. The insured must be emailed a comprehensive copy of the policy as stated in Article 36 of OIAR. The regulation obliges insurers to make sure that the insured can review, print, and download their copy of the insurance policy, as required in Article 37 of OIAR. Consumers without a solid understanding of which forms of information are needed would therefore be awarded genuine protection. A further protection would be offered by requiring insurers to send this information after the policy has issued. This would avoid the serious problems seen in Southern Rock Insurance Co. Ltd v Hafeez, where no insurance proposal was offered (Shukrī, 2011:721).

All things considered, irresponsible or intentional misrepresentation allows the insurer the right to circumvent the insurance policy, though, this right is limited by obliging it to be applied in good faith and it is the duty of the insurer to prove such irresponsibility or deliberate misrepresentation. Additionally, if the insurer fails to demonstrate irresponsible or deliberate misrepresentation, the situation will be found in the consumer's favour. No law exists that is comparable to the duty of fair presentation of risks in Saudi insurance law due to the lack of separation between the pre-contractual duties of the insured and the principle of utmost good faith, which, as we have seen, is similar to the previous UK law.

The matter of the burden of proof being on the insurer to show innocent misrepresentation is demonstrated in a number of CRIDV decisions. Such as decision No.38/J/1429 H (2008) of the CRIDV in Jeddah. While in decision No 38/D/1429H (2008) in Dammam, the insurer claimed to avoid the insurance policy on the basis that the insured had breached the doctrine of good faith by making a misrepresentation of material facts regarding their medical history. Herein, the insurer enquired about the insured's medical history, but the insured denied having any prior health issues whatsoever, thus prompting the insurer to enter into the contract.

The Committee found that the insured did not misrepresent material facts as the insurer could not specifically prove that the insured had known these facts prior to the conclusion of the policy. There are similar cases of this kind in Saudi such as decision No.73/D/1435 H (2014), which was upheld by appeal decision No.391/a/1436 H (2015) of the CRIDV in Dammam and decision No.167/R/1435 H (2014) of the CRIDV in Riyadh.

In another case the insurer refused to pay indemnities to the insured because the insurer was able to prove that the insured misrepresented their medical history, and the CRIDV accepted the insurer's refusal in decision No. 35/R/1435 H (2014) in Riyadh. 
The CRIDV found that the insured had breached the doctrine of utmost good faith (Aljallal, 2014).

However, it may be seen that Saudi jurisdiction has the duty of disclosure enshrined within it. The following section will critique and evaluate the duty of disclosure in the UK and Saudi Arabia, in its retained business insurance roles (Mahat, 2015:3).

Under Articles 2 and 5.1 of the ICPP, the duty of disclosure requires not only the provision of information to be accurate, honest, and clear with integrity and transparency, but also to abstain from concealing or dealing ambiguously with any important, inadequate, or inaccurate information to both the insurer and the insured. Importantly, this is a more effective definition of the duty of disclosure compared to its previous definition in Article 55 of IRCICCL as a requirement to reveal any information that is pertinent to an insurance policy proposal. Furthermore, the said proposal should be comprehensively considered in the event of any disagreements regarding any information provided.

As the situation currently stands, the duty of disclosure is particularly thorough since it is a duty on both parties. The proposal mirrors Article 42 of IMCCR, stating that the amount of information to be released to the insurer should be restricted to information what a reasonable person believes important to reveal (Mahat, 2015:8). One issue of the reasonable person assessment in Article 4 of ICPP requires special care to be offered by insurers to customers with learning impairments, the elderly and those with an incomplete education. This special care should cover offering advice, explaining, and simplifying the differences between policies, and guarantee full comprehension of terms and conditions.

As a result, it is clear that while the ICPP acknowledges differences between types of consumer, it does not define how a reasonable person is to be interpreted when considering these differences. Consequently, the issue to be resolved is to decide whether these given special consumer classes should be seen as a limitation to the reasonable person test, or an exemption to it. Of key importance to the issue is that it is the insurer's duty to provide the burden of proof that the insured has behaved in a manner different from a reasonable consumer, therefore demonstrating violation of the duty of disclosure (Mahat, 2015:12).

\section{Misrepresentation}

In the Saudi jurisdiction, the important difference between misrepresentation and non-disclosure is the deliberate intention to act dishonestly and in bad faith by falsifying the material facts. It is the duty of the insurer to demonstrate the burden of proof that the insured has deliberate intention to deceive and misrepresent. If this deliberate intention is not proven, then good faith should be presumed. This requirement of intent creates another condition in establishing fraud, namely that the insured intends to injure the insurer or influence the insurer's decision to participate in the policy of the specific terms or the level of premium (Mahat, 2015:3). 


\section{Conclusion}

This article has critiqued Saudi insurance regulations from two core aspects. First, the duty of disclosure is based on a number of legal regulations under Saudi jurisdiction. It is thought that this could result in consumer difficulties understanding requirements about pre-contractual duties. The article finds it preferable to cover these pre-contractual duties in one comprehensive regulation rather than several of them. Secondly, thorough terms of the insured's pre-contractual duties may be overlooked, for instance, provisions regarding the two parties' understanding of waivers, remedies, renewals and differences - all of which involve additional regulatory attention.

Moreover, in Saudi insurance law the remedies for breaching post-contractual duty of good faith are quite vague whereas within English insurance law there is a clear emphasis on avoidance ab initio. We must mention however, that there are some remedies provided for by the CRIDV for breaches of the pre-contractual duty.

The urgency of appropriate legal remedies cannot be overstated since the ICPP offers no remedies in cases of consumer duty violations. Consumer needs can only be met with clear-cut and detailed regulation. However, it must not be overlooked that Islamic contract law comprehensively covers several legal remedies including the concept of deprecation. The research therefore strongly endorses application of these theories within Saudi insurance regulation.

\section{References}

Abu Orabi, G. (2011) Insurance Contracts: a Comparative Study. Dār Waa'il. (in Arabic).

Aljallal, A.I.A. (2014) The duty of good faith in insurance law: a study of Saudi law compared to English law. T. 2. University of Southampton, School of Law, Doctoral Thesis.

Birds, J. (2016) Birds' Modern Insurance Law. Sweet \& Maxwell.

Hasson, R.A. (1969) The Doctrine of Uberrima Fides in Insurance Law: a critical evaluation. The Modern Law Review. 32 (6), 615-637.

Hodges, S. (1999) Cases and Materials on Marine Insurance Law. London, Cavendish Publishing Ltd.

Lowry, J. (2009) Whither the Duty of Good Faith in UK Insurance Contracts Whither the Duty of Good Faith in UK Insurance Contracts?" Connecticut Insurance Law Journal. 16 (1), 97-156.

Lowry, J., Rawlings, P. \& Merkin, R. (2011) Insurance Law: Doctrines and Principles. Edition $3^{\text {rd }}$. Hart Publ.

Lowry, J. \& Rowling, P. (2012) That Wicked Rule, that Evil Doctrine: Reforming the Law on Disclosure in Insurance Contracts. Modern Law Review. 75(6), 1099-1122.

Mahat, M.A.A. (2015) The Doctrine of Khiyar al-'Ayb as proposed by Muslim Jurists and its Maqāsid in Islamic Transactions. In: International Conference on Maqasid al-Shari'ah in Public Policy and Governance. Malaysia, International Institute of Advanced Islamic Studies (IAIS).

McGee, A. (2014) The Reform of English Insurance Law: Attracting Business in the $21^{\text {st }}$ Century. The Asian Business Lawyer. (16), 73-85.

Merkin, R. \& Lowry, J. (2008) Reconstructing Insurance Law: The Law Commissions' Consultation Paper. Modern Law Review. 71 (1), 95-113.

Merkin, R. (2016) What Does an Assured 'Know' for the Purpose of Pre-Contractual Disclosure? 27 Insurance Law Journal.

Merkin, R.M. (2010) Colinvaux's Law of Insurance. London, Sweet and Maxwell. 
Merkin, R. \& Gürses, O. (2015) The Insurance Act 2015: Rebalancing the Interests of Insurer and Assured. Modern Law Review, 78 (6), 1004-1027.

Merkin, R. \& Gürses, O. (2016) Insurance Contracts after the Insurance Act 2015. Law Quarterly Review. 132 (3), 445-469.

Noussia, K (2019) Transparency in the Insurance Contract Law of England. In: Pierpaolo Marano \& Kyriaki Noussia (eds.) Transparency in Insurance Contract Law. Cham, Switzerland, Springer. pp. $573-590$.

Thanasegaran, H. (2016) Good Faith in Insurance and Takaful Contracts in Malaysia: A Comparative Perspective. Singapore, Springer Science and Business Media.

Tyldesley, P. (2013) Reform at Last. In: Tyledysley P. (ed.) Consumer Insurance Law: Disclosure, Representation, and the Basis of Contract Clauses. Bloomsbury.

Shukrī, B. (2011) At-Ta 'meen fi 't-Tatbeeq al-Qadā' wa 'l-Qānūn. Dār uth-Thaqāfah. (in Arabic).

'Uthaymeen, M. (2002) Ash-Sharh Al-Mumti' Ala Zad Al-Mustaqni'. T. 11. Dār Ibn ul-Jawzī. (in Arabic).

Wang, F. (2017) Illegality in Marine Insurance Law. Abingdon, Oxon, Routledge.

\section{About the author:}

Khalaf Albalawi - Doctor, Assistant Professor of Commercial Law and Insurance Law, Law School, Tabuk University; University City, Staff Campus, Tabuk 47512, Saudi Arabia e-mail:km.albalawi@ut.edu.sa

\section{Об авторе:}

Альбалави Халаф - доктор, доцент коммерческого права, страхового права, юридический факультет, Университет Табук; 47512, Саудовская Аравия, г. Табук, Университетский городок, кампус персонала e-mail:km.albalawi@ut.edu.sa 